\title{
Why the Abuse of Human Rights by the Military in Nigeria 2015 - 2019 need to be brought to the attention of the International Community
}

\author{
T.K.Adekunle. PhD, BL.
} Senior Research Fellow, Institute of African Studies University of Ibadan, Nigeria.

\author{
Hilary Nwaechefu. LL.M, LL.B, BL, \\ Doctoral Research Candidate, University of Ibadan. Lecturer Faculty of Law Redeemer's University Ede Osun \\ state Nigeria
}

\begin{abstract}
Human rights abuses by the military in Nigeria had existed since the first military coup in 1996 till date. Some international human rights organizations had wadded into Human rights abuses by the military and made reports after conducting investigations. The primary objectives of this paper will therefore be to identify human rights challenges caused by the military in the Nigeria society. This paper will approach the Human rights abuses by the military in Nigeria by reference to statute books, Internet sources, Newspaper publications and text books. The findings in this paper, amongst others, is that despite the constitutional guarantee on human rights and the provisions of international law, the Nigeria government appear not have given due attention to check mate the military hostility. There is legislation on mode of military operation but this legislation has not been well monitored and enforced. This paper will high light some of the Human rights abuses by the military in Nigeria between 2015 and 2019 and make useful recommendations toward restoring sanity in the military activities. This paper will further make useful recommendations toward preventing future human rights abuses by the military and thereby ameliorate the hardships of the victims of brutality.
\end{abstract}

Key words: Human rights, brutality, human torture, maltreatment, investigations.

DOI: $10.7176 / \mathrm{JLPG} / 83-15$

Publication date: March $31^{\text {st }} 2019$

\section{Introduction}

The abuse of human rights by the military in Nigeria has become topical, important, and perhaps notorious which has attracted the attention and criticisms of different stakeholders, such as Judges, Lawyers, parliamentarians, political scientists, religious bodies and social commentators. Notwithstanding the persistence of concern and criticisms of different stakeholders, the abuses of human rights by the military have continued unabated in the different Nigeria communities. These unprofessional military actions have also continued to leave in their victims monumental pains, anguish and even deaths without substantial interventions by the appropriate authorities. When issues of abuse of brutality by the military are brought before the courts, some are visited with punitive award of damages against military authorities and against the rascal personnel involved. Many writers in the past and present, notably Oyewo ${ }^{1}$, Oluyede ${ }^{2}$, Malemi ${ }^{3}$ and Agbedo $^{4}$ among others have all condemned the abuse of human rights by the military and the other security agencies. Notwithstanding scholarly efforts and Judges Contributions in condemning every traces abuse of human rights, it would seem that little or nothing has been achieved to stem the tide. However there have been condemnations of late from the Nigeria parliament concerning the menace of military brutality on the civilians. In particular, the Constitution of the Federal Republic of Nigeria, 1999 (as amended), being the grund Norm makes a very clear provision on the protection of human rights of the citizens. There is no doubt that for the human rights of the citizens to be

${ }^{1}$ Constitutional Law and procedure 95-130 ( $2^{\text {nd }}$ ed.2000)

${ }^{2}$ Nigeria Administrative Law 456-487 ( $1^{\text {st }}$ ed.1988)

${ }^{3}$ Administrative Law, 109-124( $4^{\text {th }}$ ed. 2008)

${ }^{4}$ Rights of suspects and accused persons under Nigerian criminal law 150-170 ( $1^{\text {st }}$ ed.2009) 
preserved, the government of the country has to maintain some degree of proactive actions by way of legislations, monitoring and enforcement of the respect for human rights by all, the military inclusive. There is no gain saying that many Nigerians and foreigners have suffered great and unquantifiable brutalities resulting from the unprofessionalism and rascality of soldiers. The observance of the rule of law by all, the military inclusive, is an essential ingredient for the survival of Nigeria democracy and by so doing, Nigeria will gain respect among the comity of nations. This article will serve the immediate and future value for the Nigeria Legislature and the Executive in dealing with issues of human rights abuses by the armed forces. There is no doubt that a discussion of this nature will serve the immediate and future needs of democratic development and contemporary jurisprudence.

\section{Definition of Key Concepts}

Black's Law Dictionary ${ }^{1}$ defines human right thus: "The freedom, immunities and benefits that, according to modern value (Esp. at international level) all human beings should be able to claim as a matter of right in the society in which they live"

Black's Law Dictionary² further defines fundamental right thus: “A right derived from natural law or fundamental law. Constitutional law. A significant component of liberty, encroachment of which is rigorously tested by courts to ascertain the soundness of the purported government justification."

From the two definitions supplied from the Black's Law Dictionary, one can deduce that fundamental right applies more to domestic law as guaranteed by the domestic constitution, while the concept of human right is of global application.

\section{Legal frame work of this article}

i. Universal Declaration of Human rights (1948)

ii. African Charter on Human and Peoples Rights (1981)

iii. Constitution Federal Republic of Nigeria 1999 as amended

Our main attention in this discourse is onhuman rights, the rights which when breached, the breaching authority or person as the case may be, can be challenged in the competent court of jurisdiction to test the justification of the violation. We will focus on the right to dignity of human person and the right to life as enshrined under Section 34 and 33 respectively of the Constitution of the Federal Republic of Nigeria' 1999 as amended.

Human rights is a global concepts which the United Nations Organization (UNO) cherishes so much, and has by its Declaration ${ }^{3}$ enjoined member states to promote the observance and enforcement of the respect for the rights of its citizens at all times. Let us therefore draw attention to article 3 and 5 respectively of Universal declaration of Human Rights. Article 3 provides that everyone has right to life, liberty and security of person.Article5provides that no one shall be subjected to torture or to cruel, inhuman and degrading punishment

The above two cited articles above confirm the position of the world body that life and the dignity of human person must not be toyed with in any circumstances except as provided for in the Constitution of member states after due process of law of the country.

On the African environment, there is an awakening for respect of human Rights by all and sundry. To that effect, in 1979 the Assembly of Heads of States and Governments of the Organization of African Unity ( OAU), now African Union ( $\mathrm{AU}$ ), converged and drafted the African Charter on Human and Peoples Rights, which was adopted in Banjul, Gambiaand came into force on $21^{\text {st }}$ October, 1981. The Charter embraced Political, economic, social and cultural rights. The African Charter provides for the establishment of the African Commission on Human and Peoples Rights and to ensure their protection. Pursuant to these international instruments which Nigeria incidentally was a signatory and also domesticated, these international instruments

${ }^{1}$ Edited by Bryan A Garner809 (Ninth ed. 2004)

${ }^{2} I d$. at 744

${ }^{3}$ Universal Declaration of Human rights (1948) 
have become a domestic law with international flavour. This was why in Fawehinmi v. Gen Sani Abacha \&Ors ${ }^{1}$, the court of Appeal has this to say: "The African Charter on Human and Peoples Rights having been incorporated into the Nigeria organic law by legislation is enforceable in Nigeria."

The African Charter on Human and Peoples Rights stated with clarity that the dignity of human person must be honoured; human beings to be free from cruel and inhuman treatment.

Article $5(\mathrm{a})^{2}$ provides as follows: "Every individual shall have the right to the dignity inherent in a human being and to the recognition of his legal status. All forms of exploitation and degradation of man particularly slave trade, torture, cruel, inhuman or degrading punishment and treatment shall be prohibited"

The implication of the Article 5 (a) above of the African Charter and its domestication and subsequent judicial pronouncement as seen above is that, it is no longer optional for the government, organizations and individuals to respect and preserve and enforce the provisions of the charter with respect to human rights of the citizens in Nigeria. Further, this charter has created the consciousness in the heart of every leader, follower, irrespective of status and class, that human right is a tangible thing, which one can feel and embrace and defend at all times.

This paper focuses on the right to dignity of human person ${ }^{3}$ and the right to life ${ }^{4}$ which many military personnel in Nigeria do not see the need to respect and uphold. We hold the view that the violation of these two rights will be the height of governmental lawlessness or executive rascality. No other rights can be meaningfully respected if the right to dignity of human person and the right to life are disregarded; hence they are the key and chiefs of all rights, without which the other rights become meaningless to mankind. Where a human being is dehumanized or killed, what then is the meaning of other rights to such a person? This is why the respect of the right to life of a human being is the starting point. For anybody to claim to respect the right to life, he must start first by respecting the right to dignity of human person. From life hinges all other rights. There are no doubts about this fact.

The Nigeria courts have never hesitated when the opportunity shows up, in condemning any acts that degrades human person. The Judges are also human beings and would not be pleased if their human persons are degraded by any authority or human agents whatsoever;

thus in Alhaja Abibatu Mogaji \& Ors v. Board of Customs and Excise \& Anor. ${ }^{5}$, some market women as Plaintiffs instituted action against the Board of Customs and Excise and its Director. At the hearing, evidences were led and it was proved that between $30^{\text {th }}$ June and $4^{\text {th }}$ July, 1982, the market women were maltreated by the Defendants, wherewith the officials of the Customs and Excise aided by soldiers and mobile police officers who fired guns, used horsewhips and tear gas freely on the women in the process of raiding the shops of the women, searching for contraband goods. The court held that the action of the Defendants violated the fundamental rights of the Women under section 31 (9) of the 1979 Constitution of the Federal Republic of Nigeria, now section 34 of 1999 Constitution. The court condemned the action of the Defendants in the following words.

I would make an order for a declaration that the action by the custom men aided by police officers and soldiers with the use of guns, firing of same, the use of horsewhip and tear gas for the apprehension, seizure and detention of goods suspected to be prohibited as was meted to first, second, third, fourth, fifth, sixth, seventh and eight plaintiffs' witness and removal of their goods without due investigation violates the rights of the plaintiffs under the Constitution of the Federal Republic of Nigeria, not to be subjected to any inhuman or degrading treatment.

Inhuman and degrading treatment when committed, angers the Judges in Nigeria as in every democratic country where the rule of law operates, when ever such actions are brought to attention of the courts. They condemn it in the strongest terms as exemplified in the words of the court reproduced above. The courts had similarly defended dignity of human person and held that torture, slavery and servitude amounted to the violation of the right to the dignity of human person. ${ }^{6}$ The dignity of human person must therefore be respected at all time except in carrying

\footnotetext{
19 NWLR part 475, Court of Appeal710(1996)

${ }^{2}$ African Charter on Human and Peoples Rights (1981)

${ }^{3}$ Sec.34 Constitution Federal Republic of Nigeria 1999 as amended

${ }^{4} I d .$. Sec. 33

${ }^{5}$ Alhaja Abibatu Mogaji \&Ors v. Board of Customs and Excise \&Anor3 N.C.L.R. 552 at $562(1982$ )

${ }^{6}$ Uzoukwu v. Ezeonu 6 NWLR (part200) at 708 ( 1991)
} 
out of judicial order dully issued against the person in question. If a court issues an order for corporal punishment by way of flogging, then it is no longer breach of dignity of human person because it follows the due process.

For a better appreciation of the Right to life, we have reproduced the section 33 of Constitution of the Federal Republic of Nigeria below. "Every person has a right to life and no one shall be intentionally deprived of his life, save in execution of the sentence of a court in respect of a criminal offence of which he has been found guilty in Nigeria"

The African Charter on Human and Peoples Rights, says in the follows words concerning the right to life: "Human beings are inviolable. Every human being shall be entitled to respect for his life and the integrity of his person. No one may be arbitrarily deprived of this right."

Evidently therefore, the Constitution of the Federal Republic of Nigeria and other international instruments enunciated above to wit: the Universal Declaration of Human rights 1948 and The African Charter on Human and Peoples Rights 1981 have all lent credence that the right to life and the right to dignity of human person are inviolable, inalienable and must not be trampled upon unduly. The right to life is so pertinent that even if a court convicts a person of capital offence, which means such a convict would be executed to death, once such a convict appeals, any authority who executes the person while the appeal is pending has violated the appellant's right to life. No wonder the Supreme Court of Nigeria did not hide its angry feeling when it held that the execution of the appellant during pendency of the appeal amounted to violation of his right to life ${ }^{2}$.

\section{Constitutional role of the Military in Nigeria}

In spite of the lofty and credible international instruments protecting human life and dignity of human person, coupled with constitutional provisions already highlighted above which ought to be respected by all and sundry, the military inclusive, the military in Nigeria had wantonly between 2015 to 2018, the years under review, manifestly abused these two rights. The question is why the flagrant disregard for right to life and the right to dignity of human person by the personnel of the Armed Forces in Nigeria? This, we think is a question to be best answered by the military. In the course of this article, we shall proffer solutions to this incessant military rascality against the civil citizens in Nigeria. The Nigeria Constitution provides for Armed Forces with the functions of the military listed out as follows.

Section 217 (2): the federation shall, subject to an Act of the National Assemblymade in that behalf, equip and maintain the armed forces as may be considered adequate and effective for the purpose of:

(a) defending Nigeria from external aggression;

(b) maintaining its territorial integrity and securing its boarder from violation on land, sea or air;

(c) Suppressing insurrection and acting in aid of civil authorities to restore order when called upon to do so by the president, subject to such conditions as may be prescribed by the Act of the National Assembly.

If the provisions of the Constitution reproduced above are correct and true, the question is, from where then did the military derive their powers to maltreat and torture the unarmed innocent civilian citizens, foreigners inclusive, in Nigeria? The Armed Forces were constitutionally empowered to defend Nigeria against external aggression or violation on land, sea or air. There is no provision what so ever in the Constitution or any statute books for the Armed Forces to torture or murder unarmed and innocent civilian populace. The Armed Forces have no constitutional role to go after Kidnappers or Armed robbers, let alone maltreating unarmed civilian protesters. These functions the Armed Forces are arrogating to themselves are the constitutional duties of the Nigeria Police Force. All these 'operation python dance' or operation crocodile smile which the military launch in Nigeria against civil populace are unconstitutional. They are not meant to be launched for internal civil unrest and armless protest. In other instances the military personnel also kill one another without justification; what an embarrassment to Nigeria.

5. Instances of the military personnel in Nigeria breaching the rights to life and the rights to dignity of human persons within the years of 2015-2019 under review, in disregard to the International Instruments on Human Rights and the Nigeria Constitution.

\footnotetext{
${ }^{1}$ Art. 4

${ }^{2}$ Nasiru Bello v. the State, 9 NWLR part 589, 765 (1996)
} 
- It was reported that a Soldier killed motorcyclist in Ogun state in Nigeria for shunning him. ${ }^{1}$

The report was that a power-drunk soldier, Abiola Odedeji, had brought sorrow to the family of a commercial motorcyclist (locally referred to as an okada rider), a resident of Agbado, Ogun State Nigeria. Odedeji allegedly stabbed the victim, Mr Niyi James, in different parts of the body. PUNCH Metro reported that the killer soldier had visited his girlfriend, Miss Amada David, at Agbado Junction around 3.30pm on Thursday the 27 $7^{\text {th }}$ of July 2017, in company of his colleague, Damilare Oni. The soldiers went to the area, close to the Agbado Police Station, on a power bike. It was gathered that after a short discussion, Odedeji and his girlfriend decided to go out on the motorbike. The killer Soldier, Odedeji was said to have stopped Niyi. An eyewitness, who gave his name only as Akinjobi, told PUNCH Metro correspondent that the 36-year-oldcommercial motorcyclist. "The soldier (Odedeji) was angry that the motorcyclist (popularly called okada riders) said no to a military man and started flogging him with a horsewhip. Suddenly, he brought out a long knife and stabbed the man on the thigh. "He also stabbed him on the waist and stomach. We quickly alerted the police."

It was further reported that a team of policemen, led by the Agbado Divisional Police Officer, Sunday Omonijo a Chief Superintendent of Police(CSP) immediately went after the suspects. It was further learnt David was apprehended on Clem Road, Ijaiye Lagos, while some policemen chased the soldiers to Mosalasi bus stop. The informant, Mr Akinjobi, said that Odedeji stabbed one of the policemen on the arm, but they eventually arrested him and his colleague. The motorcyclist died at the Ifako-Ijaiye General Hospital Lagos Nigeria ${ }^{2}$. What a reckless waste of human life by these irresponsible and rascal soldiers.

The Ogun State Police Public Relations Officer, Abimbola Oyeyemi, an Assistant Superintendent of Police (ASP) who confirmed the incident, said the suspects would be charged to court after investigations had been concluded. He said that the case had been transferred to the Homicide Section of the State Criminal Investigation and Intelligence Department, Eleweran Abeokuta Ogun State, for further investigations and that the Nigerian Army had been contacted and the suspects would face necessary disciplinary action. ${ }^{3}$

\section{- Abuse of human rights by Nigeria Military Found to be Rampant in War Against Boko Haram}

The report had it that in the course of Nigeria's war against the Boko Haram terrorist group, at least 7,000 persons have died in government detention because of brutal conditions; an additional 1,200 have been "extra judicially executed" by Nigerian security forces, and at least 20,000 have been arbitrarily arrested by the authorities, Amnesty International (AI) said in its report released Wednesday, 1st June 2015.

Torture, mass shootings, starvation, the use of deadly fumigation chemicals in overcrowded cells have been routinely employed by the Nigerian military to lethal effect, the rights group said in the report. The abuses constitute war crimes and possible crimes against humanity, the group contended in its 133-page report. It named a number of senior officers as responsible, including the then Nigerian chief of defense staff, Alex Badeh.

Documented reports of large-scale human rights Abuse by Nigeria Military had become a recurring decimal for years, often straining relations with international partners, including the United States, in the fight against Boko Haram. In this case, the organization said it spent several years researching its report and conducted "more than 412 interviews to confirm human abuses by the Nigeria Military." 5

\section{- Soldier guns down woman on her daughter's wedding day ${ }^{6}$}

This day Newspaper reported that the incident occurred about 8.30a.m. The middle aged woman had decided to take a commercial tricycle to a relation's place near the venue of the wedding in order to make it on time as the state wide compulsory environmental exercise was in progress. The trigger happy rascal soldier had flagged

\footnotetext{
${ }^{1}$ AfeezHanafi, Soldier killed motorcyclist in Ogun State in Nigeria for shunning him (August 23rd, 2017, 2PM), www.tori.ng/newsreported

${ }^{2} i d$

${ }^{3} i d$

${ }^{4}$ Adam Nossiter, Abuse of Human Rights by Nigeria Military Found to be Rampant in War Against Boko(

June 12, 2015, 11.30AM)www.mobile.nytimes.com

5 id

${ }^{6}$ Omon-Julius Onabor, Soldier guns down woman on her daughter's wedding day

( May 13, 2016, 4PM)www.thisdaylive.com
} 
down the cyclist at Jakpa junction Delta state, Nigeria claiming that the restriction of movement was still on till $10 \mathrm{am}$. The other soldier sensing that the tricycle rider was not going to stop, then fired a shot at the tricycle and killed the woman, as the bullet hit her below the left breast. What a wanton destruction of life by irresponsible soldiers in Nigeria.

\section{- How Nigerian security forces killed 150 pro-Biafra protesters - Amnesty International}

Amnesty International (AI) reports had revealed how extrajudicial execution and torture by Nigeria security forces, especially the Nigerian Army, led to the death of at least one hundred and fifty (150) pro-Biafra protesters across Nigeria's south-east, between August 2015 and August 2016. The report titled: "Bullets Were Raining Everywhere": Deadly Repression of Pro-Biafra Activists, released on Thursday the $24^{\text {th }}$ November, 2016 and relied on the analysis of 87 videos, 122 photographs and 146 eye witness testimonies revealed that soldiers in Nigeria fired live ammunition to disperse protesters, most of them members of the separatist group, Indigenous People of the Biafra (IPOB), without warning.

According to AI, at least 60 defenceless IPOB protesters were shot dead within two days preceding the Biafra Remembrance Day of May 30 2016. The AI report corroborated PREMIUM TIMES' investigations published in June, 2016 showing the vicious clamp down and wanton executions of members of IPOB by soldiers of the Nigeria Army, the police and operatives of the Nigeria's secret police, the State Security Services (SSS). The report also exposed several acts of torture and inhuman treatment meted on those arrested by the military. It was reported by AI that the military poured acid on their victims where they kept them in a crowded ceils. Those kept in the guard room were flogged every morning, the flogging, the soldier referred to as early morning tea.

Amnesty International (AI) reported that despite overwhelming evidence of extra judicial killing and torture of protesters, no action had been taken by the Mohammadu Buhari led government to investigate and bring the perpetrators of these human rights abuses to book. AI stated that lack of accountability by the military authority and grave human right violations was also evident in the Nigeria North East where the military had engaged the Boko Haram in a lingering war. Amnesty International reporter, Mr. Kamara had called on the government of Nigeria to initiate independent investigation of crime under international law, but this action, Mr Kamara said, had not been taken despite repeated promises by president Buhari to do so.

Amnesty International had said that the government of Nigeria must ensure that reparation are paid to the victims of torture and brutality by the military; stressing further that compensation must be paid to the families of those killed and tutored to death by the military in the process of suppressing protests. AI also warned the military that fire arms should never be used for crowd control, as such actions of the military was against international law. It was only the well instructed, trained and equipped police that should control crowd in line with international law $^{2}$

\section{- $\quad$ Nigeria House of Representatives condemned Military attacks in the Niger delta. $^{3}$}

In another development of military attacks on civilian communities, the lower House of the Nigeria parliament referred to as the House of Representatives had reacted to the recent attack of Ogbobagbene Community in Burutu Local Government Area of Delta State Nigeria. The Military was said to have retaliated to the attack and the killing of a soldier at a joint military check point in the state. The House also urged the military to stop counter-attack on the people of the area. The House of Reps has ordered the Chief of Defence Staff, Gen. Gabriel Olonisakin and the military to stop further incursion of soldiers into Ekeremore Local Government Area of Bayelsa State Nigeria. The House directed the military to stop counter-attacks on the people of the area over the killing of a solder in the Ogbobagbene Community in Burutu L.G.A. of Delta State who was allegedly killed by unknown gun men. The house also called on National Emergency Management Agency (NEMA) to urgently provide reliefs to the victims of the attacks.

\section{- US Senators opposed the sale of fighter jets to Nigeria over Military Human Rights abuses ${ }^{4}$}

\footnotetext{
${ }^{1}$ Nicholas Ibekwe, How Nigerian security forces killed 150 pro-Biafra protesters - Amnesty International, (October 17, 2018, 6PM)www.premiumtimesng.com 
The Nigeria government had sought to purchase 12 A-29 Super Tucano light attack aircrafts worth $\$ 600$ million from the United States to fight and defeat Boko Haram insurgents. Reacting to this bid, two US senators wrote to the secretary of state vehemently opposed to the sale of the weapons to Nigeria, citing human rights abuses perpetuated by the Nigeria military. Two US senators in their protests cited the Nigeria failure to comply with court orders in the detention of Shiite Islamic movement's leader, Ibraheem El Zakzaky, and his wife who remain in detention without charges since December 2015. Senators Cory Booker and Rand Paul in a joint letter on Tuesday, June 8 2016, said Nigeria must display concern for human rights first. The Senators in the letter to the US Secretary of State, Rex Tillerson, cited the killing of Shiites by the army in early 2015 and the accidental bombing of an internally Displaced Persons (IDP) camp as reasons why the aircrafts should not be sold to Nigeria. They noted that although the country was facing Boko Haram insurgency, failure to comply with human rights directives shows the country should not be in custody of fighter jets with mounted machine guns and related parts and logistical support. The Senators demanded to be briefed on the steps Nigeria had taken to investigate and hold accountable those that had committed human rights abuses.

Even though the Senators agreed that Nigeria was facing security threats, they hold the view that without the Nigerian government showing a commitment to the protection of human rights and enforcement of accountability, those fighter aircrafts should not be sold to Nigeria. The law makers of the US congress maintained that there was evidence that the Nigerian military routinely flouts the laws of war. This means that the Tucano aircraft could be used in a manner inconsistent with international human rights and humanitarian law. The congress men insisted that Nigerian government must investigate into the December 2015 alleged massacre on Shiite Muslims in the north eastern town of Zaria, where at least 347 members of the Islamic Movement of Nigeria, a Shia Muslim group were killed by soldiers. It was alleged that the General Officer in command of the army had authorized the massacre. The army's attack was unjustified. An investigation launched by the local Kaduna government found that the General Officer in command of the army had authorized the massacre and recommended prosecution of those behind the unlawful killings. Nearly a year after this report was published; there has been no follow up from the federal government in Abuja, the Nigeria capital.

The two Congress men also cited the Nigerian Air Force bombing of Internally Displaced persons Camps (IDPs), which killed at least 236 people and injured thousands. There was yet the 2014 killing by the Nigerian security forces of over 600 people, on the heels of Boko Haram's attack on Giwa Army barracks. Hundreds of mostly unarmed detainees, including children, were killed in extrajudicial executions and likely buried in mass graves around the city. ${ }^{1}$

It was however later reported that United States government had approved the sale of the 12 A-29 Super Tucano light attack aircrafts to Nigeria to aid her combat the Boko Haram insurgency. This approval came after several diplomatic appeals and promises by the Nigerian government to curtail human right abuses by its security forces. ${ }^{2}$ Whether the Nigerian government will keep to the directive to respect human rights and bring those responsible for the military human right abuses to book, time will tell.

\section{- Abuse of human right to life by the Air force personnel against his colleague}

The Premium Times ${ }^{3}$ reported that A General Court Marshall of the Nigerian Air Force(NAF) on Tuesday $15^{\text {th }}$ August, 2017 sentenced Air Craftman Bernard Kalu to death by hanging for the killing of his colleaguegirlfriend, Corporal Oladipupo S. A. Kalu shot and killed Oladipupo at her Corporal and Below Quarters, Compound 9, Air Force Base, Makurdi on the allegation that she was having an affair with another man. Kalu, 21, after breaking into Oladipupo's home in the early hours of the fateful Sunday, shot her on the neck at close range, and also attempted to kill the man he met in the apartment. But his rifle got hooked, a situation that allowed the man to struggle with Kalu until he was able to disarm him. The Judge Advocate, Flight Lieutenant MA Umoh, listed the eight-count charge against Kalu to include murder, house breaking, attempted murder, failure to perform military duty, loss of service property, disobedience of service order as well as prejudice of service discipline. Umoh noted that the accused pleaded not guilty to all the eight-count charge, adding that the prosecution brought 13 witnesses, while three witnesses including $\mathrm{g}$ the accused were called by the defence counsel. Umoh maintained further that even though the prosecution adduced evidence to prove its case on all the eight-count charge, the defence, in closing their case, submitted that the prosecution did not prove the case beyond reasonable doubt.

\footnotetext{
${ }^{1} i d$. at 5

${ }^{2} I d$

${ }^{3}$ Wale Odunsi, www.dailypost.ng,(September 29, 2017, 4.25PM)
} 
Delivering judgment, President of the court, Group Capt. Elisha Bindul, who found the accused guilty on six out of the eight-count charge preferred against him, sentenced him to death by hanging subject to the confirmation of the conveying authority.

\section{- Army jailed two soldiers 10 years for abduction ${ }^{1}$}

The President of the General Court Martial \& Division, Nigeria Army sitting in Maiduguri Borno state Nigeria, Brig-Gen Olusegun Adesina had convicted and sentenced two soldiers to five years (5) imprisonment respectively for abduction and human right violation. During the trial credible evidences were led to establish that the two vagabond soldiers invaded the residence of one Alhaji Hassan on the $19^{\text {th }}$ day of November, 2017 and from his home, they led the man to his business shop at Babban Layi in Maiduguri Borno state, whereupon the rascal soldiers forcefully collected the sum of one million naira $(\$ 2,754.84)$ before they released their captive.

\section{* PDP to petition UN over Military killings during February 232019 presidential election in Nigeria}

At the recently concluded presidential election in Nigeria, reports came from journalists that the election was over militarized. It was reported that at most part of the South- South part of Nigeria the Military was use in harassing and intimidating and cajoling voter, forcing many people to flee the polling units. Chief Alabo Tonye Graham Douglas, a traditional ruler in Abonema Kingdom in Akuku-Toru Local government Area of Rivers State Nigeria expressed frustration over the military killing many persons in the area, forcing the natives to flee to neighbouring communities for safety. The Peoples Democratic Party ( PDP) whose presidential candidate, Alhaji Abubakar Atiku lost the February 232019 presidential election in Nigeria, has lamented over the heavy military presence and the resultant killing of civilians by the military. The party had concluded plans to petition United Nations over the alleged military role in the said election. ${ }^{2}$

Going by the above few reported cases of abuse of human rights by the members of the Armed Forces in Nigeria in the last five year under review, one may want to question the rationale for human rights violations by the military and the little action that had been taken to stop future violations. The military all over the world maintain nonpartisan posture or political neutrality and upholds professionalism to the core. The case is different in Nigeria where the military men take laws into their hands with impunity. It is time for positive action. The international community such as the United Nations must wade in to call Nigeria military and the government of Nigeria into order before it is too late.

\section{Suggestions for control and remediation of human right abuses by the military in Nigeria}

i. The Nigerian National Assembly must, as a matter of urgency pass a legislation stipulating stiff penalty against the use of torture and other forms of inhuman and degrading treatments by the members of the Armed forces and the other security agencies. Those who are victims of military torture must be awarded damages, and if they die in the process, their next of kin be awarded damages to the tune of two million US dollars $(\$ 2 \mathrm{~m})$. By the time the military authority pays this amount to two or more victims of torture, they military will call itself to order.

ii. Human right groups like the Amnesty International and others, including lawyers should be permitted via legislation to freely monitor the military and other detention camps across Nigeria. This will ensure that human rights abuses are detected early and will not be swept under the carpets in the usual Nigeria manners.

iii. There is the need for regular monitoring by the military police on the activities of military men. It is because monitoring has been weak, that is why the military personnel torture civilians on the streets and get away with it unnoticed and unpunished. The Chief of Defence Staff must issue a public statement making it clear that those in any military custody are entitled to access by their lawyers, families and human right groups as the case may be.

\footnotetext{
${ }^{1}$ Njadvaramusa, Army jailed two soldiers 10 years for abduction, Guardian Newspaper, October 4, 2018 at p 2
}

${ }^{2}$ The Guardian Newspaper ( Lagos, 3 March 2019) 4 
iv. Civilians should also be enlightened to take videos of the military personnel attacking civilian populace. A civilian taking such pictures and videos should stand distance away from the scene so that the sadist soldiers breaching human rights will not notice the pictures or videos being taken; thereafter such videos could then be uploaded on YouTube or other internet sites; by so doing the abuse and other human torture do not go unnoticed. Such pictures or videos should also be handed over to human rights organizations for necessary action.

v. We also suggest that a minimum of HND or B.SC in any field be made the minimum qualification for recruitment into the Armed forces. A well educated military man will be more level headed in dealing with the civilians whom he is meant to protect. The training of the military should include courses on human rights, so that military men in Nigeria will appreciate the need to respect the dignity of human person and right to life.

vi We also observe that the military personnel while dressed on military uniforms often intimidate the civilians. They perpetuate human right abuses because they know that by military exprit de corp, every military man must first of all support his fellow military man in any scuffle or fight before enquiring into the cause of the scuffle or fight. Civilians do not have such ethics. A civilian must first inquire into the cause of a quarrel before he takes side. We therefore recommend that military personnel must restrict the use of military uniform in the barracks. All military men must not be allowed to board commercial vehicles while on uniforms. This is to avoid military frequent contacts with the civil populace and minimise brutality.

If these suggestions are holistically adopted and applied, it will surely stem the tide of wanton human torture and destruction of lives by the military. There is nothing in the constitution of Nigeria or any other statute book suggesting or revealing by implication that the life of a military man is more important than that of a civilian citizen of Nigeria. The military must be kept within their constitutional relevance and stop ever stepping their boundary. The military has never in the history of Nigeria contributed a quarter to the Gross Domestic Product (GDP) up to what the civilians had contributed. They are even paid from the taxes paid by the civilians they torture and kill without justification. The military, if they are idle, the federal government should channel their idle energy in eliminating kidnappers, smugglers, armed robbers and defeat the Boko Haram insurgents or made to engage in agriculture to produce food for local consumption and for exports; by these approaches they will contribute meaningfully to the GDP of Nigeria. Will the Nigeria military have a change of attitude? Time will tell. 